\title{
The Translation Movement in the Arab World: From the Pre-Islamic Era Until the end of Umayyad Dynasty (Before 610-750 A. D.)
}

\section{Hussein Abdo Rababah}

Al-Imam Muhammad Ibn Saud Islamic University, College of languages and Translation, Riyadh, KSA

\section{Email address:}

hrababah@hotmail.com

To cite this article:

D. Hussein Abdo Rababah. The Translation Movement in the Arab World: From the Pre-Islamic Era Until the End of Umayyad Dynasty (Before 610-750 A. D.). International Journal of Language and Linguistics. Vol. 3, No. 3, 2015, pp. 122-131. doi: 10.11648/j.ij11.20150303.13

\begin{abstract}
This research is a retrospective explanatory one. It traces back the contribution of Arab translators on the global translation movement and civilization starting from the pre-Islamic era until the end of the Umayyad caliphate in 750 A. D. The importance of translation in transferring knowledge from one nation to another and from one civilization to another is well-known to every scholar and researcher. This study has revealed that the contribution of Arab translators on the global translation movement and civilization has been performed by transferring knowledge and sciences from different resources, such as China, India in the East, and Greece, Roman empire in the west into the Islamic state in the Arab lands, and then they have participated in transferring that knowledge into Europe in the high medieval ages. Moreover, this research paper has provided evidence that the transfer was not limited to sciences such as chemistry, astronomy, botany among other branches of science. It has rather extended to include arts and literature; Arab translators have translated fiction and stories from India and East Asia to Europe and the West. This study has also affirmed that Arabs, before Islam, were mainly living, in the Arabian Peninsula, they have been divided and attracted into either one of the two biggest and strongest civilizations and powers at that time; the Romans in the west and Persians in the east. In other words, Arabs didn't have at that time an independent civilization, unified state or entity. When Islam came, the situation has dramatically been changed. This will be elaborated in details in this study. This research is composed of five sections. The first section is an introduction which discusses the significance of this study and definition of related terms. The second section reviews the related literature. The third section tackles the translation movement during different stages, this implies the pre-Islamic stage and Islamic stages including the translation movement during Prophet Muhammad's life (610-632 A. D), the ruling period of the Rightly Guided Caliphs (Al klhulafa Ar rashidun) (632-661) and the Umayyad ruling stage from 662 to 750 A.D. The fourth section discusses the results and findings. The final section summarizes the study and submits suggested recommendations.
\end{abstract}

Keywords: Translator, Arab Translators' Contribution, Translation Movement, Global Civilization, in the Umayyad Dynasty

\section{Introduction}

Language is considered as the most prominent aspect of any human culture or civilization in the world, because people use it to communicate with each other, and it is usually linked with the identity of any nation. Communication by itself also plays a crucial role in transferring the cultural attributes, civilization and advancement from one generation to another and from one nation to another. The importance of translation in transferring knowledge is well-known to every scholar, researcher, and to the lay people.

Languages, which can be represented by the translation process, are the vehicles of thought and feelings among the human communities. And I would say that translators are the captains of these vehicles. No one can deny the importance of bridging the relationship between countries and nations, and overcoming the barriers between them. This can only be achieved by translation, by which mutual understanding between people and governments is accomplished. Furthermore, the transfer of knowledge, sciences and arts from one nation to another and one generation to another is comprehensively based on translation,.

The global translation movement has commenced with the creation and existence of the first human being in this world, namely Adam, when he started to communicate with angels and his partners to express his thoughts (concepts) into words. 
In Quran, which has been revealed before 1400 years, Allah says "He (Allah) taught Adam the name(s) of all things; then He placed them before the angels, and said: "Tell me the nature (names) of these if ye are right." (Al-baqara 31: Yusuf 2006: 10), in another translation for the same verse by Usmani (2007) "And He taught 'Adam the names, all of them; then presented them before the angels, and said, .Tell me their names, if you are right..." Some of Quran interpreters, for example Alqortoby tafsir (explication) translated by Yusuf 2006, states that 'names of things' in this verse refer to the equivalent names(nouns) in all original languages in this universe.

In the same Alqortoby Tafsir of Quran (2006), Kaab al Ahbar Al-himeiri, who was a narrator in Islam, said "Allah taught Adam Arabic and Syriac languages and other ancient languages". This means Allah taught Adam the names (nouns) or words, that refer to certain concepts, and their equivalents in all languages in the world and Adam had taught these words and names to his descendants. So, in my opinion, this can be considered as the initial and the first step of translation in the World history. Later on, with the development of human civilizations, people used translation to fulfill the need of communication in various human societies with different languages, as it will be discussed and explained in the following sections of this study.

This research is a retrospective historic study. It traces back the contribution and influence of Arab translators in the global translation movement and civilization. It investigates this contribution starting from the pre-Islamic era until the Abbasside dynasty (before 610-750 A D). It also sheds light on the role of Arab translators in transferring knowledge from and into the world civilizations that have existed before and after Arab prosperous civilization.

This research paper consists of five main sections, the first section is an Introduction, which includes operational definition of related terms, the significance of the study and the objectives of the research, and the second section reviews the related literature. The third section of this research discusses the stages of the Arab translation movement starting from the pre-Islamic stage until the end of Umayyad ruling period in 750 A.D. The fourth section of this research includes analysis, discussion and explanation of the findings. Finally, the last section of this research summarizes this study and sets conclusions and recommendations.

\subsection{Objectives of this Research}

i. Sheds light on the translation movement in the Arab world by tracing back the translation movement from the pr-Islamic period until the end of the Umayyad era.

ii. Identifies how have Arab translators' efforts contributed to the whole global translation movement and civilization.

iii. Highlights and identifies the progress and development of the translation movement and how it has been managed, administered, sponsored and organized in the Arab world from one era to another.

\subsection{Definition of Operational Terms}

\subsubsection{Definition of Civilization}

The word civilization is originated from the Latin word 'civilis', meaning "citizen," and implies membership in a state or country. Scholars have often described civilization as a set of attributes in certain societies including agriculture, sailing, metal working, monumental construction, writing, cities, government, currency, taxation, and religion have all been cited by scholars attempting to define what signifies civilization (Meriam-Webster Dictionary website).

A civilization is any "complex state of society characterized by urban development, social stratification, symbolic communication forms (typically, writing systems), and a perceived separation from and domination over the natural environment. The Online Dictionary defines 'civilization' as an advanced state of human society, in which a high level of culture, science, industry, and government has been reached.

\subsubsection{Definition of Translation}

It is the transfer of one linguistic production from one language to another language and it has fulfilled and met the original purpose in the text of the source language (SL or L1) text and it is a skill, by which the translator replace the text and meaning of the source language by a text and meaning in the target language (T1 or L2) (Kharma 1979 my translation, and Sokolovsky 2010). This definition is similar to Newmark's definition (2001:21): "Translation is a craft consisting of the attempt to replace a written message and/or statement in one language by the same message and/or statement in another language".

\subsubsection{The Translator}

The translator is the person who carries out the procedure of translation. So, the translator's "task is to create conditions under which the source language author and the target language reader can interact with one another" (Lotfipour, 1997). The translator uses "the core meaning present in the source text to create a new whole, namely, the target text" (Farahzad, 1998). A good translator is someone who has a comprehensive knowledge of both source and target languages (Razmjou 2004).

\subsection{Significance of the Study}

The significance and importance of this research comes from the global importance of translation in general as well as Arabic situation in the world, because the role of language in the developing world is materialized through translation (Razmjou 2004). Most people know that Arabic is spoken and written by about 300 million inhabitants of the Arab world, but few realize that Arabic script is familiar to more than one billion and half of people in the World. For example Persian (Farsi), Urdu, Pashto languages speakers and people in all Muslim countries such as, Indonesia, Malaysia, Nigeria and many more

The significance of this study lies behind the translation profession, though the translators' efforts are usually forgotten or marginally mentioned. Translators usually play the role of 
the third party; who is basically absent in the process of knowledge transmission. People usually consider the author or title of the book and they forget the translator. In this regard, Allen (2004) (cited in Siddiek 2010), argues that translation is a notoriously thankless profession: there is absolutely no money in it; it involves a severe submersion of the self into another; the hours are long and you get about as much recognition for your efforts as the telephone repairman. (Wortsman 2010 cited in Siddiek 2010) holds the same idea that he had all but given up translation. So by conducting such research, researchers could highlight the importance of the translation in the World civilization.

So, the role of the translator is as important as the importance of the original scientific work that the translator intends to translate. The Translator's task goes parallel with the original knowledge product. It is expected to produce the same effect if it has been perfectly transferred into the target language. In this context, I would say the translator who is able to translate a good and useful book from L1 (Language 1) to an influential and useful book in L2 (Language 2) has done a great job by producing the same effect on the target society, so he can be considered as the second author of that book but in L2. Thus, the significance of this study lies in the importance of the translator's role and his/her translation outcome and its relationship with the global civilization.

\section{Review of Literature}

After reviewing the related literature, one can conclude that the translation movement has been carried out in different directions:

i. The first direction was from Greek and Roman civilization in the West into the Arab world, This has been taken place in the 7th century with advent of Islam, as Islam encouraged Muslims to learn and translate

ii. The second direction was from the Far East including India and China to Arabs in the Middle East and Arabia Peninsula, such as the translation of Kaleilah WA Demnah, one thousand and one nights.

iii. The third direction was from Arab World towards Europe in 12th century which will not be discussed in this research paper.

Types of Translation in the History of Arabs are

i. Freelance translators or interpreters, such as Zaid Ibn Thabet who translated Prophet Muhammad's letters.

ii. Institutional Translation type, such as Bayt-ul-Hikmah in the Abbasside era which will not be discussed in this study.

iii. Specialists or scholars of different knowledge branches have played the role of translators, for example, in medicine; most translations in different domains of medicine were done by specialists, they have translated books related to their scientific specialties.

As previously mentioned, Arab scholars and translators' contributions were of two different directions; the first direction was transferring knowledge and science from Romans; namely Greek Byzantines, who were the last rulers of Romans in the West in the medieval ages. The second way was transferring knowledge from Persians and Indians, and even Chinese in the East to Arabs, who used to live in, what is called nowadays, the Middle East region, then later in the medieval ages to Europe in the West. From the East, they have translated different books into Arabic, such as Abdullah Ibn Al-Muqaffa, as Kalīlah wa Dimnah from Sanskrit, the ancient Indian language, is an ancient Indian collection of inter-related animal fables in verse and prose, arranged within a story.

The transfer had also implied the transfer of knowledge from one historical era or civilization to another; in other words from one powerful nation to another. Arabs have transferred knowledge from pre-Islamic civilization to the Islamic Civilization and later to the European or Western Civilization. This transfer of knowledge has taken place through effective and active translation movement. The translation movement took place through different stages that will be discussed in the following section.

\section{The Stages of the Translation Movement in the Arab World}

The stages of Arab translators' contribution are chronologically classified as follows

\subsection{The Pre-Islamic Stage (Before 610 A. D.)}

Before Islam, Arabs were mainly living, in the Arabian Peninsula, between the two biggest and strongest civilizations and powerful empires at that time; the first one was the Roman Empire from north and west, and the second one was the Persian Empire from East. Arab tribes had been attracted and divided into either one of these two powers. In other words, Arabs didn't have at that time a separate and independent civilization, unified nation or state. Moreover, they didn't have a great effect in the world. When Islam came, the situation had dramatically and totally been changed. They have formed their own new state and nation; it is the state of Islam, as Islam has played a great role in its identity, culture, civilization, prosperity and development. This will be discussed and explained in more details in this study.

Although, little documents are available concerning the translation activities in the pre-Islamic stage, it is expected that Arabs, however, had translation activities in their life, because they used to travel in what is called "the Journey (caravan) of summer and winter" by which they travelled from Arab peninsula to the Levant lands, Ethiopia and Yemen. These journeys were lead by Quraysh tribe, one of the famous Arab tribes used to live Mecca and Medina in the Arab Peninsula at that time, they are both located in the Kingdom of Saudi Arabia nowadays. they were commercial journey in nature, in which they travelled to Ethiopia and Yemen in winter and to Bilad Ash-sham (East Levant) (modern Syria, Palestine, Jordan and Lebanon nowadays); it is also called the Fertile Crescent.

This has been documented and stated in the Holy Quran before about 1400 years in "It is a great Grace and Protection 
from Allah), for the taming of the Quraysh, (And with all those Allah's Grace and Protections for their taming, We cause) the (Quraysh) caravans to set forth safe in winter (to the south), and in summer (to the north without any fear", (Dar Assalam online Publications 2014:106. Surah Al-Quraysh), and they are translated by Yusuf 2006 "For the accustomed security of the Quraysh -"Their accustomed security [in] the caravan of winter and summer (Surah Quraysh 10: 1 and 2). Most scholars say that each caravan used to take six months from the time of travelling from Makah to the time of return from Ethiopia or Yemen in winter or from Ash-sham (East Levant or Syria region nowadays) in summer. In this regard, it is known that trade and even warfare can spread ideas and result in the desire to gain access to the best ideas that others have (Yusuf 2006 and Usmani 2007). So, communication between people with different languages will only take place and be achieved by the presence of translators or/and interpreters.

Presumably, through these journeys, Arabs have made contact with at least three nations at that time; Persians in the East, Romans in the North and West, and Ethiopians in the South, and these nations had different languages, Pahlavi language (old Persian) for Persians and Old Latin for Romans and Greek for Byzantines and Ge'ez or Ethiopic for Ethiopians, which is still used today as the liturgical language in the Ethiopia and part of Eritrea.

Therefore, a journey with such length and different communication modes or languages, it is logically impossible to make such economic and commercial relationships without having a certain sort of translation facilities and proficient translators, who helped those travellers and merchants to communicate with other peoples. There is also an archaeological evidence of such translation activities, it is a manuscript dating back to $513 \mathrm{~A}$. D, found near Aleppo, and written in Greek, Syriac and Arabic. It includes, among other things, the names of men involved in building the church where the manuscript was found (Hourani, 1991).

So, the translation movement before Islam period was limited to the mutual and commercial interests, communication and contact between Arab tribes represented by Quraysh from one side and other neighbour nations, such as Romans, Persians, Al Manathirah and Al Gasasinah from the other side. Although, this translation movement was existed, and there are no enough documents available about its nature, but logically there should have been some sort of translation activities available at that time in order to fulfil Arabs and other peoples' communication needs.

\subsection{The Translation Movement in the Islamic State}

Islam existed in 610 A.D with its new basic principle urging people to search for knowledge and understanding this universe, because Islam believes that the possession of knowledge is the best way of understanding this world; by which a man can understand and realize the relationship between the creation and creator. This in turn will help in discovering and solidifying the truth and faith of Allah, who is the creator (God) of this universe, and people will glorify Him in accordance with this understanding. So Islam adopted this principle and tried to disseminate this belief into the world.

In this regard, T. S. Eliot explained that the great world cultures (or civilizations) Byzantine, Medieval, Islamic, Chinese, among other civilizations, have been established on a religious revelation. Each revelation is transmitted to other nations and generations by the power of tradition. "It is through this social and artistic deployment which we call "tradition" that the original revelation comes to permeate, and imprint its particular stamp on, every sector of collective life" (cited in Stoddart 2008: 13).

Additionally, the time of the prophet Mohamed (Peace be upon Him) is significant and important in the translation history, because new Islamic and religious terms have been introduced to Arabic and later translated to other languages in the world. The spread of Islam and the communication with non-Arabic speaking communities as Persians, Assyrians, Romans and others motivated the prophet to look for translators and to encourage the learning of foreign languages. One of the most famous translators at that time was Zaid Ibnu Thabet, who played a crucial role in translating letters sent by the prophet to kings of Persia, Syria , Rome, and the replied letters sent by those kings to the prophet ( Khan 2009 and Al-Jawziah 2003).

Islamic teachings have also given a high value to education and learning, and historians agree that the early Muslims were open-minded to accept and adopt the civilization and science heritage of others or in the lands they have ruled. From the first day of revealing Quran to Prophet Muhammad, the first verse revealed to Prophet Muhammad, Angel Gabriel asked him to "Proclaim! (or Read!)(1) In the name (2) of thy Lord and Cherisher, Who created-Created man, out of a (mere) clot of congealed blood (3) Proclaim! And thy Lord is Most Bountiful (4) He Who taught (the use of) the Pen (Surah 96:1-4, Al Alaq, The Clinging Clot or 'Iqra' or 'Read': Yusuf's translation 2006: 457). So seeking and searching for knowledge is the first and vital principle of Islam; in other words, gaining knowledge can only achieved either by conducting scientific research or by translation of others' research results or scientific works.

Moreover, another evidence for the keenness of Islam to have literate and educated followers and acquire the world knowledge is that, in the first battle of the history of Islam, the battle of Badr, which was the first battle between Muslims and atheists, Muslims captured fifty prisoners in that battle; some of them were freed for redemption. Those prisoners, who could not pay redemption but could read and write ; in other words they were literate, were asked to teach Muslim children how to read and write as compensation for their redemption and a condition to be released, and when they did, they were freed, whereas prisoners, who were poor and had no money, were released without any redemption or condition.

So, bearing this crucial concept in Muslims' minds has motivated them to proceed and start learning, looking for knowledge and acquiring it from their neighbor nations, this also requires translation of sciences and knowledge from all available resources, origins and languages. As Islam spread out, Arabs and Muslims have met different established 
civilizations and centers of learning. Arab translators have started transferring and translating the knowledge available in these centers. Thus, a new era of translation has been evolved.

This translation movement in the Islamic era can be divided into sub-stages according to the ruling system existed in each stage. The first sub-stage (stage) took place with the Prophet's Muhammad life or existence, the second stage occurred during the Ruling period of the four Rightly Guided Caliphs (Al klhulafa Ar rashidun), the third sub-stage is the Umayyad's stage, and the fourth or final stage is the Abbasid stage; these stages will be discussed in more details in the following sections except the Abbasid stage which will be discussed in another upcoming research paper. However these stages are overlapped and the borders of each stage are not clearly landmarked. The first stage, for example, could be considered as the preparatory stage for the following one and a part of the whole translation process; whereas the second stage is considered as the complementary stage to the first one and as another step for the following one and so on.

Therefore, I can re-classify the stages of the translation movement in the Arab World with the advent of Islam in a different way, other than the classical and chronological classification one, they can be classified according to their contribution to the global civilization as follows:

i. The receptive stage: It includes the beginning of the Islamic era, because during these periods Arabs were mainly receiving and transferring knowledge from others without great scientific intervention or development from their side. This stage includes the beginning of the Islamic stage during the Prophet Muhammad' life, the stage during the ruling period of the four Rightly Guided Caliphs (Al klhulafa Ar rashidun) and the beginning of the Umayyad era.

ii. The productive stage: the translation movement in this stage has reached its utmost prosperous peak and achieved its fruitful objectives and goals. It includes the late stage of the Umayyad era and the third stage of the Islamic translation movement, namely the Abbasids' stage.

This classification is similar to the classification of language acquisition process which includes the receptive and productive stages. It is based on the knowledge acquisition. For instance, at the beginning of Islam, the translation movement was limited in just transferring knowledge from other languages into Arabic, so, I call it the receptive stage. But in the second stage (The productive stage), Arab scholars started to introduce, argue, criticize, invent, initiate, add their own opinions, develop others' ideas and innovate new ideas based on scientific background and embody them with Islam thinking and understanding. So, they have become productive and creative to the global civilization and knowledge fields, and the translators' task and role have become very crucial and significant too. Additionally, I can say that every stage of the translation movement has simultaneously implied the receptive and productive processes.

\subsubsection{The Translation Movement During Prophet Muhammad's Life (610-632 A. D)}

As early as the seventh century, in the year 610 A. D., Quran was revealed to Prophet Muhammad (Peace be upon Him) in the Arabian Peninsula. It has marked the appearance and advent of Islam, a new religion in the world. It was revealed in Arabic. So, the Arabic language and Islam have become inseparable. As Muslims started moving in all directions in order to disseminate the mission of Islam, they became in need for translating their knowledge written in Arabic with the new concepts and religious terms to others, and translate and understand the languages of others. So, they basically needed to have translators and interpreters during their movements and campaigns.

For example, it is well documented in history that Prophet Muhammad has sent different letters to a number of rulers and kings who were ruling areas and lands around the Arabian Peninsula, such as Heraclius, Emperor of Byzantines (Eastern Roman Empire), Chosroes II (Emperor of Persian Empire), Harith Gassani, the governor of Syria, Negus, king of Abyssinia (Ethiopia), Muqawqis, the ruler of Egypt among others, urging them to adopt the new religion of Islam ( Khan 2009 and Al-Jawziah 2003).This type of correspondence, exchange and communication between the Prophet and non-Arab rulers could not have taken place without using a sort of translation or interpretation. Moreover, the Quran itself includes many words arabicized and borrowed from Greek, Persian, Syriac and other languages, such as istabraq and sundus among others (Baker 2001). This is another evidence for the presence and exchange of linguistic expressions and words between Arabic and other languages and peoples and a proof for the presence of translation activities.

\subsubsection{The Translation Movement During the Ruling of the Rightly Guided Caliphs (Al Klhulafa ar Rashidun) (632-661)}

After the death of Prophet Muhammad, Islam has expanded its territory out of Arabia Peninsula into Egypt, Syria and Iran rapidly. By the end of the 7th century, Muslims, who were basically represented by Arabs, governed lands stretching from Spain in the west to the borders of China in the east. These countries had different languages, such as Persian in Iran and Sanskrit and Urdu languages in the Indian Continent. North and westwards were Romans; their language was Latin. This means that opening or adding new countries to the Islamic state, several languages, civilizations and cultures have been added to the growing state.

Accordingly, the communication between those speakers of different languages and Arabs could not have been taken place without a sort of translation. So, it is expected that Muslim campaigns to places out the Arab peninsula included translators and used translation in order to communicate with those different nations and peoples with different languages. Moreover, with the spread of Islam came the spread of the Arabic language across Afro-Euro-Asian lands from Central Asia to the Atlantic Ocean. Muslim governments established centers and schools for teaching Arabic, collecting and 
translating scientific, literary, and philosophical works of all nations.

However, following the death of the Prophet Muhammad in 632, Islam was led by a series of four caliphs who have known the Prophet and were his companions. They were known collectively as the Four Rightly Guided Caliphs (Al klhulafa Al- Rashidun in Arabic); they formed what is called Al-Rashidun Caliphate. This ruling era was characterized by the followings:

i. It was a short period of ruling

ii. The rulers were busy in stabilizing the internal socio-political situation of the Islamic state.

iii. They have faced internal challenges as well as external ones. These challenges divert the Rightly Guided Caliphs' (Al klhulafa Al- Rashidun) attention from developing the translation movement and other scientific issues, they were rather busy in sorting out different socio-political issues, as it will be explained in the following section.

The Rightly Guided Caliphs (Al-Rasheedun Caliphate) are:

i. Abu Bakr (632-634 A. D.): He ruled the Islamic state for only two years and he faced many challenges, especially the Rebels from some Arab tribes who threatened the authority and unity of the Islamic state, by rejecting Islam and refusing to obey Abu Bakr, so he was very busy in restoring the order and stabilizing the Islamic community. The Islamic community also faced border threats from the Roman and Persian Empires. In 633 the Caliph Abu Bakr defeated that revolt (known as a ridda) or apostasy and thereby secured the whole Arabian Peninsula for Islam. So, it is expected that during this ruling era, little work has been done for the translation movement, except those translation activities related to the communication with people from Persians or Romans at the borders of the Islamic state.

ii. Omar ibn al-Khattab, ( 634-644 A. D)

iii. He launched the first waves of conquest beyond Arabia, and ruled for 10 years. Under Omar reign, the Islamic empire expanded at an unprecedented rate ruling the whole Sassanid Persian Empire and more than two thirds of the Eastern Roman Empire. Omar also established the public treasury which controlled the financial affairs of the Islamic state. Cities were built with irrigation canals and paved roads, and education in the Quran became more widespread. He also codified the Islamic law. He decreed that the Islamic calendar should be counted from the year of the Hijra of Muhammad from Mecca to Madinah (Campo 2009). With this expansion of the Islamic territories during Caliph Omar's reign, it is expected that there was obviously a demand on teaching Quran and Arabic. So, this could have been achieved by the presence of bilingual teachers or /and interpreters and translators.

iv. Othman ibn Affan (644-656 A D.) Othman is the Caliph who codified the Quraninto its final orthographic form which is namely Arabic. With the growth of a multilingual population in the Islamic state during his ruling period, Othman ordered the Quran to be compiled in a single unified dialect by forming a committee who compiled the basic text of the Quran as it exists today.

v. It was important to develop a standardized orthography and writing system in order to eliminate the regional, dialectal and linguistic variations that existed in the Arab world. This work was undertaken due to the vast expansion of Islam under Othman's rule, the Islamic empire expanded into Iran and some areas of Khorasan (present-day Afghanistan, which encountered many different dialects and languages. This had led to variant readings of the Quran for those converts who were not familiar with the language. So translated versions of the interpretation of Quran was necessary to be available (Natheer 2001). Othman was originally a trader and a son of a rich and trader family, so bilingualism was expected to accompany his caravans and commercial communication.

vi. Ali ibn Abi Talib (656-661 CE) - During this period however, Muawiyah ibn Abi Sufyan (Muawiyah I) and Amr ibn al-As controlled the Levant and Egypt regions independently of Ali. His rule as caliph was plagued with internal troubles and hostilities. Therefore, there were insufficient documents about this period. However, it is expected that Caliph Ali has followed the steps of his preceded caliphs and the same steps of the Prophet Muhammad (Peace be Upon Him)

\subsubsection{The Translation Movement during Umayyad Ruling Era (661- about 750 A.D.)}

General Information and Historical Background

The Umayyad dynasty was established by the caliph Muawiyah I (Mu'awiya) in 661. Caliph Muawiyah, previously governor of Syria, inaugurated dynastic rule. From their capital city at Damascus, the Umayyad caliphs ruled a vast empire, extending from Europe to India, until 750. After the Umayyad dynasty was overthrown by Abbasids, it continued in Spain in the west until 1031.

So, Umayyad Caliphate was divided into two main parts, the first one was in the east which ruled (661-750) from Damascus as its capital city with different caliphs; started with Muawiyah I ibn Abu Sufyan (661-680), Yazid I ibn Muawiyah (680-683), Muawiya II ibn Yazid (683-684), and ended with Marwan II (744-750). The second part of Umayyad dynasty was ruling the west part of the Islamic state including Spain, and Cordoba was the capital city for the Umayyad Emirs of (Spanish Umayyad Caliphs 929-1031), started with Abd-ar-rahman I, 756-788, Hisham I, 788-796, al-Hakam I, and ended with Hisham III, 1027-1031. An Umayyad prince, Abd-ar-Rahman I, took over the Muslim territory in Al-Andalusia (Hispania) and founded a new Umayyad dynasty there.

The first or east part of Umayyad Caliphates or dynasties started in 661 and ended in 750, so it lasted about ninety years, and during that time, as mentioned previously, Islam spread from China in the east to Spain in the west. In this era, the translation of scientific books into Arabic has already begun, but the translation movement under the Abbasids, who 
succeeded the Umayyads, was greater and more comprehensive.

The Umayyad dynasty has made a great task related to the translation movement; it is the adoption of Arabization or Arabicization, by which Arabic was considered as the official and common language or mode of communication within the empire. This can also be considered as a major step of language planning made in the Islamic state or Arab world at that time.

The translation process in the Umayyad period is considered as the first stage or the corner stone of the whole Arab translation movement in the Islamic time. However, if we compare the Umayyad translation movement and its accomplishments with other Islamic periods of translation, such Abbasid one; we can easily conclude that the translation movement in this era was limited in quantity and quality. The amount of translated works was limited in number, as it included only the translation of the basic and natural sciences. For example, medicine, or chemistry which was involved in the Umayyad translation movement, as it is important for preparing the medical prescriptions and recipes for patients by physicians, but it didn't' comprehensively tackle the translation of logic, mental sciences, psychology and philosophy books among others.

The translation movement into Arabic during the Umayyad's reign began under the rule of Omar bin Abd Alaziz who was one of the famous Umayyad caliphs; he encouraged and supported translators and worked for the sake of knowledge and science. Prince Khalid ibn Yazid was also one of the famous translation supporters. His situation as a member of the ruling family in addition to his enthusiasm and efforts had undoubtedly contributed in the transfer and spread of knowledge (Ibn Al Nadeem, n. d.). He, himself, was also one of the famous translators in the First Hijri century (700 A.D); he and other translators had translated books of medicine, chemistry and mental subjects. He was interested in sciences such as alchemy, so he requested to translate the works of Greek or Byzantine philosophers and scientists. He rewarded the translators generously, and they also translated Greek, Persian and Egyptian books into Arabic (Bahri 2011).

As Islam expanded, Muslims did not destroy but preserved others' cultures, because their main goal was to revert people ask them to adopt and spread the Islam mission. Furthermore, they absorbed and used the technology and sciences of these civilizations to produce and develop a new knowledge and Arab-Islamic civilization, which was the beacon for humankind for hundreds of years. For example in the Persian Empire land, which is called Iran nowadays, Muslims left the Academy of Gundishapur (in Arabic was called Jundishapur) intact and later added to its knowledge treasures. This Academy was the intellectual center of the Sassanid Empire (Persians); it was founded by Sassanid king Shapur I. It included a teaching hospital, big library and centre of higher education. This Academy had also included Indian works, such as Indian mathematics, including Hindi numerals, called Arabic numerals today, were also introduced to Muslims during this time. The Abbasid Muslim rulers ordered to translate the works at Jundishapur and other places in the Sassanid Empire into Arabic. So it is expected that Arab translators have carried out this task (Mathews n.d. and Bahri 2011).

\section{Discussion, Findings and Analysis}

From the previous findings and review of literature, one can conclude that the translation movement has started slowly in the pre-Islamic and has been developed in the Islamic era, and in the Islamic Umayyad era, it has been accelerated and developed. The most important periods in the history of translation movement and its contribution on the global civilization into Arabic are the Umayyad and Abbasid periods, which were followed by a long period of translation (recession) in the Islamic World from the twelfth to the eighteenth centuries, as mentioned by Baker (1998). However, in my opinion, I would say that there was no complete recession of the translation in the Umayyad's stage or in any other stage, because translation is an indispensible need for every nation in the world at any time or in any place. So, I would prefer to say that there was no substantial development in the translation movement during a certain period of time better than saying recession, because there should have been a sort of translation or interpretation activities during all stages and ages between nations in the world.

It is worthy noted that the translation process was the first basic ground for the scientific development which has followed this translation stage. Therefore, translation was first used as a transferring stage of science and knowledge. Then, it was converted to be used as the corner stone of the whole Arab and Muslim civilisation. In other words, it served as a method or means to achieve a goal but not the end goal by itself. Arabs have translated astrology, medicine, and other sciences, as well as they have developed them later.

The quality of the translation products are also expected to be of less quality than the Abbasids' translation works, because the translation movement in the Abbasid's period was institutionalized, more organized and controlled by Bayt-ul-Hikmah, as it will be discussed in another research paper. I would refer the limitations of the translation products in Umayyad dynasty era to the following reasons:

i. The first reason was the limited care and support of caliphs, because they were involved in several socio-political and military issues, especially during the beginning period of the Umayyad's dynasties.

ii. The second reason is that caliphs were busy in establishing and strengthening the administrative institutions and departments of the new Islamic state.

iii. The limited budget of the newly established state and the most financial expenses were mainly directed to the military weapons and equipments and supporting the armed campaigns.

Despite all of these limitations, this translation stage is considered as the milestone of the whole translation process in the Arab World. Arab translators have started translating the basic branches of science and knowledge, such as medicine, 
chemistry among others, because they are necessary for human life. Then, after Islam ideas, thoughts, beliefs and teachings had become stronger and more solid in the minds of Muslims, they moved a step farther by translating books of Greek theology, philosophy and logic, as they had no fear of hurting Islam at this stage.

Therefore, the most famous and important scientific works, books and references have been translated into Arabic from different languages. The work of Arab translators was neither anarchic nor chaotic one; it had rather been planned, organized, managed, systemized, had plans and targets, and they were supported to a certain limit by the Islamic state and government.

This study has revealed that there are several factors helped in developing and accelerating the translation movement from the pre-Islamic stage until the end of the Umayyad era, they can be summarized as follows:

i. The existence of Arabs between two powerful, civilized, educated and developed empires around the Arab lands, in addition to the need for building up commercial relationships with the neighbouring states and empires.

ii. The motivation and encouragement of Islam to learn from all sources in the world, as Islam has considered the search and acquisition of knowledge as one of its ordinances and it is an individual as well as the society responsibility, duty and obligation. Islam as a religion doesn't separate the knowledge of life from its basic principle or the knowledge of the second life; therefore Muslim scientists were scholars in Islam as well as in any secular science such as medicine, philosophy, astrology or any other branch of knowledge, for example Ibn Al Nafis or Ibn Sina, Ibn Rushd among other scientists.

iii. The translation process was also supported by certain rich and known people and families, such as Othman Ibn Affan among others (Al-kasimi 2006)

iv. The efforts of the translators themselves which cannot be neglected. Because they exerted their utmost efforts to produce the best translated versions, this can be inferred from the process and stages of translation they used to apply in translation later in Bayt-ul-Hikmah activities in the Abbasside dynasty.

v. The interest and willingness of the scientists and scholars themselves to translate certain original copies of famous scientific or literary books, such as Hippocrates and Aristotle's works and Kalilah wa Dumnah among others.

vi. The motive of Arabs and Muslims to spread and disseminate the mission and teachings of Islam in worldwide that are inseparable from Arabic as it is the liturgical and religious language and the language of Islamic teachings. Therefore, wherever Islam extends and spreads, knowledge in Arabic was translated into other languages and knowledge of other languages was also translated into Arabic.

vii. The need and will of Arabs for transferring the civilisation and technological development to the world, especially after the expansion of the Islamic state from China in the east to Spain in the west. viii. The linguistic characteristics of Arabic, especially the presence and availability of different word formation techniques, such as derivation, diminution among others, the flexibility of the Arabic language, the richness of its terminology corpus, and its high capacity and big stock of expressions and words, have helped in coping with the new scientific concepts and coining new terms.

\section{Summary, Conclusions and Recommendations}

The contribution of Arab translators to the global translation movement and civilization from the Pre-Islamic stage until the end of the Umayyad Caliphate in 750 A. D. have been discussed and identified in this research. The translation activities during that period of time have implied all branches of knowledge, such as medicine, chemistry, astrology, botany among others. The process and efforts of translation were carried out by individuals, such as Khalid ibn Zaid and Zeid Ibn Thabit among others. However, it was supported to a certain extent and limited degree by Caliphs and rich families such as Caliph Othmani Ibn Affan among others.

This period of translation was important at the global level of translation movement for the following reasons:

i. Arab translators have firstly translated important books of different branches of knowledge such as philosophy, medicine, mathematics, literature and other sciences from all over the world into Arabic, and they have added information and knowledge to them, and later they have retransferred and retranslated them into European languages. This in turn had a great impact on the global civilization.

ii. Arab translators started to be specialized in a specific language and specific branch of knowledge, this has enhanced the quality of the translation. For example, some of them were specialized in translating Syriac, Greek, Persian or Latin works.

iii. They developed the translation process and made an important profession and they developed and changed it from the stage of individual and freelance translators to the institutional stage.

iv. They have also made Arabic the official language for people living in a vast geographical area extending from China in the East to Spain in the west. So, Arabic became the scientific language as well as the mode of communication at that time. This step can be considered as language planning process made to Arabic.

v. Arab translators have transferred the master pieces of scientific and literary books into Arabic, this in turn has helped in preserving the knowledge of others and transmitting it to the following generations of Arabs and non-Arabs in the whole world.

Thus, Arab civilization has absorbed every key idea and knowledge of old Greek and Roman (Byzantine) sciences and added to it what they have known and learnt from Persia, India and China. "Certainly, one of the great achievements of the 
human intellectual spirit was the Arabic translation movement On the course of about one hundred years, virtually the entire Greek scientific and philosophical corpus was either translated or summarized into Arabic" (Davis 2010: 12). Then, Arab translators and scholars have published them in paper-made books with the invention of paper and the encouragement of Caliphs and rulers of the Islamic state who have encouraged the translation of every major and important scientific work into Arabic.

These paper-made books have been retranslated into Europe with the participation and help of Arab translators. The modern western science and knowledge primarily originated from the study of these Arabic books, and then they have been retranslated into Latin and other European languages.

So, if we try to deny the role of Arabic or/and Arab translators, we can all conclude, assume and agree that Arabic has at least played the role of a reservoir of knowledge; it has preserved knowledge for about six centuries and then transferred it to the world. It has covered all branches of science - medicine, chemistry, astronomy, mathematics and physics. Arab scholars have additionally added eminent information, inventions and theories to the original knowledge and then they transferred it to modern world. This great transfer job has basically been carried out by the efforts and contribution of Arab translators.

Finally, knowledge is a collective and accumulative process to which all cultures, past and present, have contributed. A great deal of this knowledge is preserved and augmented through a highly creative and rigorous process known as translation. Medieval Arabic translators did really contribute to the development and preservation of human knowledge Menocal (2005). Arab translators transferred the translation movement and process from ad hoc activity into an organized and institutionalized movement and they have changed it to a scientific approach by moving it into a scientific profession. Through their huge translated books in different fields, Arab translators have helped in the development of this world civilization to reach our contemporary technological civilization. This translation movement was unprecedented in the transmission of knowledge in the whole history of humankind.

\section{References}

[1] Al-Jawziah, Ibn Qaiem (2003) Za'd Al-Ma'ad, translated as "Provisions of the Hereafter", Dar-us-Salam Publications.

[2] Al-kasimi, A. (2006) The effect of translation on the recognition of the other and the perception of the self (Torjomiāt [Tradictology], "Atar Attarjama Fi Ma'arifat addāt wa idrāk al akhar). Rabat : Edition of Racines.

[3] Bahri, H. (2011) The Role of Translation Movements in the Cultural Maintenance of Iran, Translation Journal, Vol. 15, No.4.

[4] Baker, M (2001) in Baker, M. and Gabriela Saldanha ( 2001 eds.) Arabic Tradition, from Routledge Encyclopedia of Translation Studies, Routledge.
[5] Campo, J. (2009) Encyclopedia of Islam, InfoBase Publishing.

[6] Davis, B. (series ed.) (2010) The Great Medieval Thinkers (Avicenna Chapter), Oxford University Press

[7] Farahzad, F. (1998) A Gestalt Approach to Manipulation in Translation. Perspectives: Studies in Translatology, 6 (2): $153-233$

[8] Hourani, A. (1991) A History of the Arab Peoples, The Belknap Press of Harvard University Press.

[9] Ibn $\mathrm{Al}$ Nadeem (n. d.) Alfahraset. http://al-hakawati.net/arabic/civilizations/72.pdf, accessed on the 25th Jan. 201

[10] Khan, M (2009) the Translation of Sahih Bukhari, Islam house Website.

[11] Kharma, N. (1979) Lights on the contemporary Linguistic Studies (Adwa'a ala Aldirasat al-lighawieh Almuasirah), A Series of the World of Knowledge (Alam AlMarifah) issued by the National Council of Culture, Arts and Literature-Kuwait.

[12] Lotfipour, S.K. 1985. Lexical Cohesion and Translation Equivalence, Meta, XLII, 1, 185-92.

[13] Matthews, J. (n. d.) The Arab Influence on the Italian Renaissance http://faculty.ed.umuc.edu/ jmatthew/naples/blog27.htm\#arab inf

[14] Retrieved on 20th of Jan. 2015 http://www.islamawareness.net/Europe/Italy/rennaissance.html

[15] Menocal, M, (2005) The Culture of Translation, Available at URL:http://www.wordswithoutborders.org/article.php?lab $=\mathrm{Cu}$ lture, (Accessed Jan. 10, 2015)

[16] Natheer, A. (2001) Islam in Global History: From the Death of Prophet Muhammad to the First World War, American Institute of Islamic History and Cul, 2001, p. 34. ISBN 0-7388-5963-X.

[17] Newmark, P. (2001) Approaches to Translation, Shanghai: Shanghai Foreign Language Education Press.

[18] Ramzjou, L. (2004) to Be a Good Translator, Translation Journal, Volume 8, No. 2

[19] Shaban, A. (1971) (The Abbasid Revolution 600-750), chapter in Islamic History, Cambridge University Press.

[20] Siddiek, A. (2010) the Impact of Translation on Language Acquisition and Knowledge Transfer in the Arab World. European Journal of Social Sciences - Volume 16, Number 4 (2010

[21] Sokolovsky, Y. (2010) On the Linguistic Definition of Translation, Journal of Siberian Federal University. Humanities \& Social Sciences, Vol. 2 (2010 3) 285-29

[22] Stoddart, W. (eds. De Azevedo, M. and Queiroz, A.) (2008) Traditional and Modern Civilizations World Wisdom, from the World Wisdom online library: www.worldwisdom.com/public/library/default.aspx

[23] Usmani, M. (2007) Translation of Quran, Quranic Studies Publishers

[24] Yusuf, Ali (2006) the Meaning of the Noble Qur'an, retrieved in Dec 2014 from http://www.pdf-koran.com/Koran.pdf. 
[25] http://www.dailykos.com/story/2011/02/19/947158/-Islamic-H istory-The-Four-Rightly-Guided-Caliphs

[26] Islamic History: The Four Rightly Guided Caliphs by Ojibaw 2011, accessed 4th Jan 2015, http://www.muslimheritage.com/article/abbasids\%E2\%80\%99 -house-wisdom-baghdad

[27] Meriam-Webster Dictionary http://www.merriam-webster.com/

website:
[28] Online http://dictionary.reference.com/browse/civilization

[29] Oxford Learners

Dictionaries: http://www.oxfordlearnersdictionaries.com

[30] Wikipedia: http://en.wikipedia.org/wiki/Civilization
Dictionary, 